\title{
HUBUNGAN KEHILANGAN GIGI ANTERIOR DENGAN ESTETIKA, GANGGUAN BICARA DAN STATUS NUTRISI PADA PENGUNJUNG PUSKESMAS DI KOTA BANDAR LAMPUNG
}

\author{
Sri Murwningsih*, Sri Wahyuni* \\ *Jurusan Teknik Gigi Poltekkes Tanjungkarang \\ Email: naning.jtg@gmail.com
}

\begin{abstract}
Kehilangan gigi dapat mempengaruhi kemampuan seseorang untuk mengunyah sehingga berubahnya pilihan makanan dan proses pencernaan yang mengakibatkan terjadinya malnutrisi, menimbulkan ketidakpuasan dari segi estetika dan gangguan bicara. Tujuan penelitian ini adalah untuk mengetahui hubungan antara kehilangan gigi anterior, usia, jenis kelamin dan tingkat pendidikan dengan status nutrisi, gangguan estetika, dan gangguan. Rancangan penelitian ini adalah analitik dengan pendekatan cross sectional. Pengambilan sampel dilakukan dengan teknik purposive sampling. Jumlah sampel sebanyak 30 orang pasien pengunjung yang mengalami kehilangan gigi anterior. Data dikumpulkan dengan angket penelitian dan lembar observasi. Analisis menggunakan Univariat, bivariat dan multivariat. Analisa bivariat dengan uji statistik chi-square dengan tingkat kepercayaan 95\% dan tingkat kemaknaan $(\alpha) 5 \%$ dan analisa multivariat dengan uji statistik Regresi Logistik. Pada uji regresi tahap terakhir didapatkan variabel yang paling dominan berhubungan adalah umur dengan $p$ - value $=0,03$. Dapat disimpulkan bahwa hanya terdapat dua variabel yaitu umur ( $p$ value $=0,03$ ) dan jenis kelamin ( $\mathrm{p}$-value $=0,04$ ) yang berhubungan dengan variabel terikat Gangguan Estetika. Variabel yang paling dominan berhubungan dengan gangguan estetika adalah variabel umur dengan $p$ value $=0,03$.Perlu upaya peningkatan promosi kesehatan kususnya dalam hal kebersihan dan perawatan gigi tiruan baik melalui penyuluhan langsung maupun berbagai media kepada masyarakat. Perlu peningkatan layanan perawatan prostodonti dengan biaya terjangkau oleh masyarakat di Puskesmas.
\end{abstract}

\section{Kata Kunci: Kehilangan Gigi, Gangguan Estetik, Gangguan Bicara}

\section{LATAR BELAKANG}

Kehilangan gigi merupakan akibat dari berbagai faktor yang berhubungan dengan kesehatan, gaya hidup, dan sosiodemografi. (Wang TF, et al, 2014). Penyakit yang berhubungan dengan kehilangan gigi adalah karies dan penyakit periodontal. Berdasarkan data WHO, prevalensi kedua penyakit tersebut sangat tinggi di dunia yaitu hampir seluruh orang dewasa mengalami karies dan $15-20 \%$ mengalami penyakit periodontal (WHO, 2014).

Status ekonomi yang rendah dan wanita juga dihubungkan dengan prevalensi kehilangan gigi yang lebih tinggi daripada orang dengan status ekonomi yang tinggi dan pria. (Wang TF, et al, 2014). Faktor lain yang tidak kalah pentingnya adalah usia dimana peningkatan usia dikaitkan dengan peningkatan jumlah gigi yang hilang. Hal ini terbukti dari data riskesdas tahun 2013 yang menunjukkan bahwa kehilangan gigi paling sedikit terjadi pada usia 12 tahun sedangkan paling banyak pada usia 65 tahun ke atas.Kehilangan gigi akan berdampak buruk pada manusia karena gigi merupakan komponen

yang penting dalam rongga mulut. Dampak paling buruk adalah terganggunya fungsi mastikasi yang akan berpengaruh terhadap pemilihan makanan, sehingga nantinya mempengaruhi asupan makanan seseorang dan status nutrisinya (Zarb G, et al, 2012). Menurut Departemen Kesehatan RI, status nutrisi atau status gizi berarti adanya keseimbangan antara jumlah asupan zat gizi dengan jumlah yang dibutuhkan oleh tubuh untuk berbagai fungsi biologis seperti pertumbuhan fisik, perkembangan, aktivitas dan produktivitas, pemeliharan kesehatan, dan lain-lain (DepKes RI, 2006).

Gigi yang hilang dan tidak diganti dapat menyebabkan berbagai kerugian yang pada awalnya terjadi adalah timbulnya ketidaknyamanan (Zarb G, et al, 2012). 
Kehilangan gigi juga memberikan efek negatif pada individu karena akan menimbulkan celah dan ruangan kosong yang mengakibatkan ketidakpuasan dari segi estetika. Dampak ini cukup signifikan dan lebih dirasakan pada wanita karena wanita lebih perhatian terhadap estetika sehingga berpengaruh terhadap psikologis dan kepercayaan diri dalam kehidupan sosial. Kebanyakan wanita tidak berani tersenyum dan malu semenjak gigi anteriornya hilang. Peningkatan permintaan terhadap perawatan gigi dari segi estetik semakin meningkat belakangan ini. Penelitian oleh Elias dan Sheiham menyimpulkan bahwa pasien cenderung mencari perawatan penggantian gigi anterior (depan) dibandingkan posterior (belakang).

Fungsi lain yang terganggu karena hilangnya gigi adalah fungsi bicara. Hilangnya gigi anterior dapat menyebabkan pengucapan dan pelafalan dari huruf-huruf yang memerlukan kontak antara lidah, bibir dan gigi anterior menjadi sulit seperti huruf s, sh, t, f, d, n, z, v (Owen CP, 2000). Hal ini mengakibatkan bicara orang tersebut menjadi kurang jelas.

Status nutrisi dapat berkembang menjadi malnutrisi, yaitu keadaan gizi kurang atau gizi lebih karena asupan zat gizi dibawah atau di atas kisaran asupan yang dianjurkan dalam waktu lama (persagi, 2009). Malnutrisi jika tidak ditangani dapat menyebabkan peningkatan insiden penyakit. Idealnya seluruh gigi yang hilang harus diganti dengan gigi tiruan agar fungsi gigi kembali seperti semula. Namun pemakaian gigi tiruan tampaknya belum menjadi prioritas bagi penduduk Indonesia yang mengalami kehilangan gigi. Hanya sekitar $14,5 \%$ yang menggunakan gigi tiruan dari $58,8 \%$ penduduk yang memiliki fungsi gigi tidak normal (Depkes RI, 2008). Kehilangan gigi dapat berakibat terjadinya malnutrisi, gangguan estetika sehingga berdampak pada psikologis dan kepercayaan diri terutama gigi anterior.

\section{METODE}

Jenis penelitian adalah kuantitatif dengan metode analitik dan pendekatan potong lintang (cross sectional.) Informasi data dari pengukuran variabel bebas (independent) dan variabel terikat (dependent) diambil pada waktu yang bersamaan dengan cara wawancara dan pengukuran antropometri serta pemeriksaan status gigi pada pasien pengunjung puskesmas di kota Bandar Lampung yang mengalami kehilangan gigi anterior.

Populasi pada penelitian ini adalah pasien yang berkunjung ke puskesmas di Kota Bandar Lampung, dengan jumlah sampel sebanyak 30 responden yang diambil dengan teknik purposive sampling.

Peneliti melakukan pencatatan biodata responden dan pengisian kuesioner Mini Nutritional Assesment (MNA). Kemudian melakukan pemeriksaan gigi anterior yang hilang dari subjek yang dibantu 10 orang operator. Selanjutnya dilakukan pengukuranberat badan dan tinggi badan. Seluruh data dikumpulkan dengan lember kuesioner dan lembar observasi.

Analisis data dalam penelitian ini adalah analisa Univariat untuk memperoleh deskriptif dengan distribusi frekuensi seluruh variabel yang akan diteliti. Analisa Bivariat dilakukan dengan uji chi square dan analisis multivariat dengan uji Regresi Logistic.

\section{HASIL}

\section{Analsis Univariat}

Dari seluruh sampel pada penelitian ini yang berjumlah 31 orang, sebagian besar responden berjenis kelamin perempuan $(83,9 \%)$, berusia $45-59$ tahun $(51,6 \%)$, berpendidikan SMA $(58,1 \%)$, gigi anteriornya hilang $0-6$ buah $(77,4 \%)$, mengalami gangguan bicara $(67,8 \%)$, mengalami gangguan estetika $(67,8 \%)$ dan tidak mengalami gangguan nutrisi $(87,1 \%)$. 


\section{Analisis Bivariat dan Multivariat}

Tabel 1: Pemodelan Awal Hubungan Antara Status Nutrisi dengan Umur, Jenis Kelamin, Pendidikan dan Jumlah Gigi Hilang

\begin{tabular}{|c|c|c|c|c|c|}
\hline \multicolumn{6}{|c|}{ Status Nutrisi } \\
\hline Variabel & S.E & Wald & $\mathrm{df}$ & Sig & $\overline{\operatorname{Exp}(\mathrm{B})}$ \\
\hline Umur & $-1,6891,463$ & 1,383 & 1 & 0,240 & 0,185 \\
\hline Kelamin & $2,063 \quad 1,799$ & 1,315 & 1 & 0,251 & 7,866 \\
\hline Penddkan & $1,645 \quad 1,175$ & 1,958 & 1 & 0,162 & 5,179 \\
\hline $\begin{array}{l}\text { Gigi Anterior } \\
\text { Hilang }\end{array}$ & 0,513 & 0.099 & 1 & 0,752 & 1,671 \\
\hline Constant & $-2,4114,548$ & 0,281 & 1 & 0,596 & \\
\hline
\end{tabular}

Pada tabel ini, variabel jumlah gigi anterior yang hilang yang mempunyai nilai yang paling besar $(0,752)$ dimana lebih besar dari nilai $\mathrm{p}=0,05$, sehingga harus dikeluarkan.

Tabel 2: Pemodelan Akhir Hubungan Antara Status Nutrisi dengan Umur, Jenis Kelamin, Pendidikan dan Jumlah Gigi Hilang

\begin{tabular}{cccccccc}
\hline \multicolumn{8}{c}{ Status Nutrisi } \\
\hline Variabel & $\beta$ & S.E & Wald & df & Sig & Exp (B) \\
\hline Peddkan & 1,054 & 0,658 & 2,569 & & 0,109 & 2,869 \\
\hline Constant & $-0,119$ & 1,196 & 0,010 & 1 & 0,9921 & 0,888 \\
\hline
\end{tabular}

Pada tahap akhir ini (keempat), variabel pendidikan juga dikeluarkan karena nilai $\mathrm{p}$ yang lebih besar dari 0,05 , sehingga tidak ada variabel independen yang paling berhubungan dengan status nutrisi pada pasien kehilangan gigi anterior.

Tabel 3: Pemodelan Awal Hubungan Estetika dengan Umur, Jenis Kelamin, Pendidikan dan Jumlah Gigi Anterior Yang Hilang

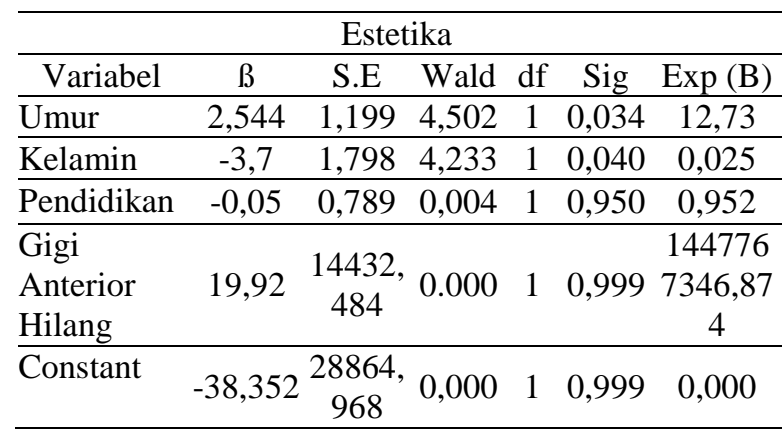

Pada tabel ini variabel jumlah gigi anterior yang dikeluarkan karena nilai yang lebih besar dari $0,05(0,999)$.

Tabel 4: Pemodelan Akhir Hubungan Estetika dengan Umur, Jenis Kelamin, Pendidikan dan Jumlah Gigi Anterior Yang Hilang

\begin{tabular}{lccccccc}
\hline \multicolumn{9}{c}{ Estetika } & & & \\
\hline Variabel & $\beta$ & S.E & Wald & df & Sig & Exp (B) \\
\hline Umur & 2,836 & 1,169 & 5,897 & & 1 & 0,015 & 17,073 \\
\hline Kelamin & $-4,468$ & 1,864 & 5,747 & & 1 & 0,017 & 0,011 \\
\hline Constant & 1,821 & 2,682 & 0,461 & 1 & 0,497 & 6,179 \\
\hline
\end{tabular}

Pada tahap akhir (ketiga) variabel yang paling dominan berhubungan dengan variabel independen pada kehilangan gigi anterior untuk estetika adalah umur dan jenis kelamin dimana nilai $p$ lebih kecil dari 0,05.

Tabel 5: Pemodelan Awal Gangguan Bicara dengan Umur, Jenis Kelamin, Jumlah Gigi Anterior Hilang dan Pendidikan

\begin{tabular}{lcccccc}
\hline \multicolumn{7}{c}{ Bicara } \\
\hline \multicolumn{1}{c}{ Variabel } & $\beta$ & S.E & Wald & df & Sig & Exp (B) \\
\hline Umur & $-0,608$ & 0,613 & 0,983 & 1 & 0,321 & 0,544 \\
\hline Kelamin & 0,831 & 1,232 & 0,455 & 1 & 0,500 & 2,295 \\
\hline Pendidikan & 0,396 & 0,553 & 0,513 & 1 & 0,474 & 1,486 \\
\hline $\begin{array}{l}\text { Gigi Anterior } \\
\text { Hilang }\end{array}$ & $-0,007$ & 1,197 & 0.000 & 1 & 0,995 & 0,993 \\
\hline Constant & $-2,081$ & 3,289 & 0,400 & 1 & 0,527 & 0,125 \\
\hline
\end{tabular}

Pada tahap pertama pada tabel ini variabel jumlah gigi anterior yang hilang dikeluarkan karena nilai $\mathrm{p}$ lebih besar dari 0,05 yaitu 0,995 .

Tabel 6: Pemodelan Akhir Gangguan Bicara dengan Umur, Jenis Kelamin, Jumlah Gigi Anterior Hilang dan Pendidikan

\begin{tabular}{lccccccc}
\hline \multicolumn{9}{c}{ Bicara } & & & \\
\hline Variabel & $B$ & S.E & Wald & df & Sig & Exp (B) \\
\hline Umur & $-0,460$ & 0,588 & 0,610 & 1 & 0,435 & 0,631 \\
\hline Constant & 0,086 & 1,108 & 0,006 & 1 & 0,938 & 1,090 \\
\hline
\end{tabular}

Pada tahap terakhir, variabel umur yang dikeluarkan dari tabel karena nilai $p$ lebih besar dari $0,05(0,435)$, sehingga tidak ada variabel independen yang berhubungan 
dengan gangguan bicara pada pasien yang mengalami kehilangan gigi anterior.

\section{PEMBAHASAN}

Pada penelitian ini didapatkan bahwa umur, jenis kelamin, pendidikan dan jumlah gigi anterior yang hilang tidak mempunyai hubungan yang signifikan dengan status nutrisi dari pasien yang berkunjung pada puskesmas di kota Bandar Lampung. Hal ini tidak sesuai dengan keterangan yang diperoleh dari hasil penelitian De Marchi RJ, et al (2012) yang menyatakan bahwa kehilangan gigi mempengaruhi indeks massa tubuh, dimana data dari National Diet and Nutrition Survey tahun 2001 menunjukkan bahwa orang dengan jumlah gigi asli $<21$ buah akan cenderung mengalami obesitas 3 kali lebih besar dibandingkan dengan yang memiliki 21- 32 gigi asli.

Demikian juga dengan faktor usia dimana Foster dan Gariballa dalam penelitiannya menyimpulkan bahwa lansia yang berusia 75 tahun atau lebih memiliki status nutrisi yang lebih buruk dibandingkan dengan lansia yang berusia kurang dari 75 tahun. Kenaikan usia juga berkaian erat dengan status nutrisi yang buruk. Hal ini tidak didukung dari jumlah sampel penelitian yang masih kurang dan usia obyek penelitian tidak menyebar dengan merata dimana pada umumnya obyek penelitian terdiri dari lansia dan pra lansia.

Pada faktor jenis kelamin, pria dan wanita berbeda dalam kebutuhan akan nutrisi. Menurut data Kementerian Kesehatan, pada semua kelompok umur penduduk dewasa, kelebihan berat badan lebih tinggi pada wanita dibandingkan pria (Kemenkes RI, 2012) padahal pria cenderung mengkonsumsi lebih banyak makanan dibanding wanita. Hal ini tidak terjadi pada penelitian ini karena sebagian besar obyek pada penelitian ini adalah wanita.

Beberapa penelitian menunjukkan bahwa semakin tinggi tingkat pendidikan seseorang, pola makan, asupan nutrien, dan status nutrisinya lebih baik dan semakin baik pula skor MNA (Chen SH, 2007). Hal ini juga tidak sejalan dengan hasil penelitian ini karena sebagian besar obyek penelitian mempunyai tingkat pendidikan yang rendah.

Dari hasil penelitian Esan TA disebutkan bahwa laki-laki lebih cepat mengalami kehilangan gigi dibandingkan dengan perempuan karena laki-laki lebih aktif dan lebih tidak perduli terhadap perawatan giginya. Penelitian ini sesuai dengan penelitian Eklund et al dan Marcus et al yang menyatakan bahwa perempuan memiliki lebih banyak permintaan terhadap gigi tiruan dibandingkan laki-laki.Trulsson pada penelitiannya juga menyatakan bahwa perempuan lebih khawatir terhadap penampilannya yang berhubungan dengan gigi dan akan merasa lebih malu pada saat berinteraksi sosial dibandingkan dengan lakilaki bila giginya tidak terawat.

Dari faktor umur umumnya kelompok lansia telah beradaptasi dengan keadaan hilangnya gigi baik dari fungsi pengunyahan maupun estetik walaupun lebih memilih jenis dan tekstur makanan yang lebih lembut serta merasa ada gangguan dalam berbicara. (Nurlitasari, 2012)

Kehilangan gigi dapat menyebabkan terganggunya fungsi bicara. Hilangnya gigi anterior menyebabkan pelafalan huruf-huruf yang memerlukan kontak antara lidah,bibir dan gigi anterior menjadi sulit seperti pengucapan huruf $\mathrm{s}$, sh, $\mathrm{t}, \mathrm{f}, \mathrm{d}, \mathrm{n}, \mathrm{z}, \mathrm{v}$ sehingga bicara orang itu menjadi kurang jelas (Owen CP, 2000). Alat bicara yang tidak lengkap dapat mempengaruhi suara penderita misalnya pada pasien yang kehilangan gigi depan atas dan bawah. Kesulitan bicara dapat timbul meskipun hanya bersifat sementara.

\section{KESIMPULAN}

Dari hasil penelitian ini untuk variabel bebas yaitu umur, jenis kelamin, tingkat pendidikan, status ekonomi, jumlah kehilangan gigi, lokasi kehilangan gigi, pekerjaan, hanya dua variabel yang berhubungan paling dominan dengan estetika yaitu variabel umur dan jenis kelamin.

Berdasarkan simpulan tersebut, perlu diupayakan peningkatan health promotion khususnya mengenai gigi tiruan terutama 
pada masyarakat yang belum pernah mendapat penyuluhan dengan pemberian brosur atau leaflet. Perlu juga ditingkatkan sistem pelayanan kesehatan gigi dan pelayanan prostodontik dengan biaya yang terjangkau oleh seluruh lapisan masyarakat terutama di puskesmas. Selanjutnya hasil penelitian ini juga dapat dijadikan dasar untuk memberi masukan kepada pemerintah dalam menyusun kebijakan dan program pelayanan kesehatan gigi dan mulut dengan menggunakan jasa asuransi kesehatan sehingga seluruh lapisan masyarakat dapat menjangkau perawatan kesehatan gigi dan mulut terutama untuk gigi tiruan.

\section{DAFTAR PUSTAKA}

Chen S-H. (2007). The Relationship Among Nutrition Self-Efficacy, Health Locus of Control, andNutritional Status in The Taiwanese Elderly. Journal of Clinical Nursing, 15-16.

De Marchi RJ, Hilgert JB, Hugo FN, Padilha DM. (2012). Association Between Number of Teeth, Edentulism and Use of Dentures with Per in South Percentage Body Fat in South Brazilian Community-Dwelling Older People. Gerodontology. 69-76.
Depkes RI. (2006) Glosarium Data \& Informasi Kesehatan. Jakarta: Pusdatin Kemenkes RI.

Kemenkes RI. (2014). Laporan Riskesdas 2013. Jakarta: Puslitbangkes Kemenkes RI.

Nurlitasari, DF. (2012). Faktor yang Berperan terhadap Permintaan Gigi Tiruan pada Lansia. Thesis. Universitas Indonesia.

Owen CP. (2000). Fundamental of Removable Partial Dentures. 2nd ed. Tokyo: Juta and Company Ltd.

Persagi. (2009). Kamus Gizi. Jakarta: Penerbit Buku Kompas.

Wang TF, Chen YY, Liou YM, Chou C. (2014). Investigating Tooth Loss and Associated FactorsAmong Older Taiwanese Adult. Arch Gerontol Geriatric. 446-453.

World Health Organization. (2014). Oral Health Fact Sheet. Switzerland: WHO.

Zarb G, Hobkirk J, Eckert S, Jacob R. (2012). Prosthodontic Treatment for Edentulous Patients. Meryland: CV Mosby. 